\title{
EFFECT OF MEPIQUATE CHLORIDE AND NITROGEN FERTILIZATION APPLICATION TIME ON THE EGYPTIAN COTTON CULTIVAR GIZA 80
}

\author{
EMARA, M.A. ${ }^{1}$, E.A. MAKRAM ${ }^{1}$, OLFAT H. EL-BAGOURY ${ }^{2}$ AND
}

\author{
A.M. EL-MARAKBY ${ }^{2}$
}

1. Cotton Research Institute, $A R C$, Giza

2. Department of Agronomy, Faculty of Agriculture, Ain Shams University, Cairo (Manuscript received 23 November 2008)

\begin{abstract}
This study was carried out at Sids Agric. Res. Sta., Beni-Suef governorate, Egypt, during 2003 and 2004 seasons. The experimental design was randomized complete blocks with four replications, using the Egyptian cotton cultivar Giza 80 ( $G$. barbadense $\left.L_{\text {.) }}\right)$. The treatments were the combinations between nitrogen fertilization in two doses $(30+30 \mathrm{Kg} \mathrm{N} /$ fed.) and three doses $(20+20+20 \mathrm{Kg} \mathrm{N} / \mathrm{fed}$.) and splitting the dose of mepiquate chloride to two doses $(25+25 \mathrm{~g}$ a.i./fed.) or three doses $(25+12.5+12.5 \mathrm{~g}$ a.i./fed. $)$ or $(12.5+25+12.5 \mathrm{~g}$ a.i./fed.). The spraying time was at pine head square, at the beginning of flowering and after flowering by two weeks. The obtained results revealed that final plant height at harvest, length of internodes, days to appearance of first flower and first boll was decreased significantly in case of plant treatment by mepiquate chloride. While, number of open bolls per plant, yield of seed cotton per plant and per feddan, micronaire reading and specific leaf weight were increased significantly by applying mepiquate chloride. Number of fruiting branches, upper half mean length and seed index were increased by mepiquate chloride in one season. Number of nodes per plant, fresh/dry weight ratio, boll weight, number of plants at harvest, lint percentage, uniformity index, fiber strength, fiber elongation percentage, reflectance and yellowness were insignificantly affected. The highest yield of seed cotton was obtained from the treatments of two or three doses of nitrogen fertilization application plus mepiquate chloride splitting dose $(12.5+25+12.5 \mathrm{~g}$ a.i./fed.).
\end{abstract}

\section{INTRODUCTION}

Mepiquate chloride (Pix) partially inhibits the synthesis of the plant hormone gibberellic acid which is involved in cell elongation and multiplication and generally vegetative growth (Makram et al., 1981). Concerning the effect of mepiquate chloride on plant growth, it reduced plant height without affecting number of nodes per plant, while the length of internodes decreased (Makram, 1988). Abdel-Al (1998) found that mepiquate chloride had no effect on number of fruiting branches per plant. Specific leaf weight, specific leaf area and fresh/dry weight ratio were affected by mepiquate chloride treatments (York, 1983a and Munier et al., 1995). Mepiquate chloride also increased boll number and improved the yield Sawan et al. (2006) and Stephen et 
al., (2007). However, Ibrahim \& Moftah (1997) found that application of mepiquate chloride reduced vegetative growth but increased the yield and its components.

Regarding the yield and its components, i.e, number of open bolls per plant, boll weight and yield per plant were increased by applying mepiquate chloride (Kassem \& Namich 2003). Abdel-Al et al., (1986) showed that mepiquate chloride increased the yield, but it did not affect boll weight. El-Shahawy \& Abd El-Malik (2000) found that mepiquate chloride improved the earliness of the yield.

Nawar et al.,(1986) and Johnson (2005) indicated that mepiquate chloride increased fiber length, fiber elongation, maturity ratio and micronaire reading, while Steve et al., (2003) found that mepiquate chloride had only a significant effect on fiber strength. Frank et al., (2005) reported that mepiquate chloride had no effect on fiber quality parameters.

Therefore, this investigation was carried out to achieve the effect of mepiquate chloride at different growth stages under different applications time of nitrogen fertilization on growth, yield and fiber quality of cotton.

\section{MATERIALS AND METHODS}

Two field experiments were carried out at Sids Agric. Res. Sta., Beni-Suef governorate, during 2003 and 2004 seasons, using the Egyptian cotton cultivar Giza 80 ( $G$. barbadense L.).

The experimental design was randomized complete blocks with four replications, the size of each plot was $26 \mathrm{~m}^{2}$ including eight rows each of $0.65 \times 5.00$ $\mathrm{m}$. Distance between hills were $25 \mathrm{~cm}$ and leaving two plants per hill at thinning time, five week after sowing. The sowing dates, i.e. on March 18 and 20 during 2003 and 2004 seasons.

The mechanical and chemical analysis of the experimental sites is presented in (Table 1). 
Table 1. Mechanical and chemical analysis of soil samples for the experimental sites in 2003 and 2004 seasons.

\begin{tabular}{|c|c|c|c|}
\hline \multirow{2}{*}{\multicolumn{2}{|c|}{ Soil characters }} & \multicolumn{2}{|c|}{ Seasons } \\
\hline & & 2003 & 2004 \\
\hline \multicolumn{4}{|c|}{ Mechanical analysis } \\
\hline Clay & $(\%)$ & 51.84 & 51.69 \\
\hline Silt & $(\%)$ & 27.81 & 27.73 \\
\hline Sand & $(\%)$ & 18.41 & 18.90 \\
\hline Organic matter & $(\%)$ & 1.94 & 1.68 \\
\hline Texture & & Clay loam & Clay loam \\
\hline \multicolumn{4}{|c|}{ Chemical analysis } \\
\hline $\mathrm{Ph}$ & & 7.83 & 7.55 \\
\hline E. C. & & 0.57 & 0.47 \\
\hline $\mathrm{Ca} \mathrm{CO}_{3}$ & $(\%)$ & 2.63 & 2.80 \\
\hline Available nitrogen & (ppm) & 36.76 & 32.88 \\
\hline Available phosphorus & (ppm) & 34.53 & 31.65 \\
\hline Available potassium & (ppm) & 392 & 472 \\
\hline $\mathrm{Fe}$ & (ppm) & 8.85 & 4.60 \\
\hline $\mathrm{Cu}$ & (ppm) & 3.23 & 3.60 \\
\hline $\mathrm{Zn}$ & (ppm) & 1.05 & 1.00 \\
\hline $\mathrm{Mn}$ & (ppm) & 31 & 15 \\
\hline
\end{tabular}

The experimental treatments which represented the combinations between nitrogen fertilizer treatments by using urea $(46.5 \% \mathrm{~N})$ and mepiquate chloride spraying time (1, 1-dimethyl piperidinium chloride) at two or three growth stages, i.e., Pine Head Square (P.H.S), Start of Flowering (S.F) and after Start Flowering by two weeks (2W.S.F), at the rate of $50 \mathrm{~g}$ a.i./feddan are presented in Table (2).

Table 2. Nitrogen fertilization and mepiquate chloride application time treatments.

\begin{tabular}{|c|c|c|c|c|c|c|}
\hline \multirow{3}{*}{$\begin{array}{r}\begin{array}{c}\text { Teartment } \\
\text { Splitting }\end{array} \\
1 \text { (control) } \\
\end{array}$} & \multirow{3}{*}{$\begin{array}{c}\text { Nitrogen fertilization } \\
\begin{array}{c}(60 \mathrm{Kg} \mathrm{N} / \mathrm{fed} .) \\
(30+30)\end{array}\end{array}$} & \multicolumn{5}{|c|}{$\begin{array}{c}\text { Mepiquate chloride } \\
(50 \mathrm{~g} \text { a.i./fed. })\end{array}$} \\
\hline & & \multicolumn{2}{|c|}{ (P.H.S) } & \multirow{2}{*}{$\frac{(\mathrm{S} . \mathrm{F})}{0}$} & \multicolumn{2}{|c|}{ (2W.S.F) } \\
\hline & & 0 & + & & + & 0 \\
\hline 2 & $(30+30)$ & 0 & + & 25 & + & 25 \\
\hline 3 & $(30+30)$ & 25 & + & 12.5 & + & 12.5 \\
\hline 4 & $(30+30)$ & 12.5 & + & 25 & + & 12.5 \\
\hline 5 & $(20+20+20)$ & 0 & + & 25 & + & 25 \\
\hline 6 & $(20+20+20)$ & 25 & + & 12.5 & + & 12.5 \\
\hline 7 & $(20+20+20)$ & 12.5 & + & 25 & + & 12.5 \\
\hline
\end{tabular}


Five representative hills were chosen by random from each plot to study the following traits,

A- Growth characters, Final plant height $(\mathrm{cm})$, number of nodes per plant, internode length $(\mathrm{cm})$, number of fruiting branches per plant, specific leaf weight (SLW $\mathrm{mg} / \mathrm{cm}^{2}$ ), specific leaf area (SLA $\mathrm{cm}^{2} / \mathrm{mg}$ ) and fresh weight/dry weight ratio $(\mathrm{g})$.

B- Yield and yield components, Number of open bolls per plant, boll weight ( $\mathrm{g}$ ), seedcotton yield per plant $(\mathrm{g})$, number of plants remained at harvest, seed-cotton yield per feddan in Kentars, lint percentage and seed index $(\mathrm{g})$.

C- Earliness characters, Number of days to appearance of first flower and first open boll.

D- Fiber quality, Measured by HVI according to (A.S.T.M. D-4605-86), upper half mean length (U.H.M) in mm, uniformity index (U.I), fiber strength (g/tex.), fiber elongation percentage, micronaire reading, reflectance $(\% \mathrm{Rd})$ and yellowness $(+b)$.

The data obtained were subjected to statistical analysis according to the procedures outlined by Snedecor and Cochran (1980) using M Stat-C microcomputer program for randomized complete blocks design. L.S.D. values at $5 \%$ level of significance were used for all treatments to compare between means.

\section{RESULTS AND DISCUSSION}

\section{A- Effect of application time treatments of mepiquate chloride and nitrogen fertilization on growth characteristics}

\section{1- Effect on plant height at harvest, number of nodes per plant, length of internode} and number of fruiting branches per plant

Results present in Table (3) and illustrated in Fig. (1) clear that final plant height at harvest was increased significantly in favour of the control plots in the two seasons. Within the mepiquat chloride the treatments of $(1 / 2+1 / 2 M C)$ with $(1 / 2+1 / 2 N)$ or $(1 / 3+1 / 3+1 / 3 \mathrm{~N})$ produced taller plants of $(119.3$ and $110.2 \mathrm{~cm}$. or 121.0 and $104.9 \mathrm{~cm}$. in 2003 and 2004 seasons, respectively). These results revealed that mepiquate chloride terminated plant height as compared to the control plots, beside that, partitioning the dose in three sprays seems to be better in controlling the lateral plant growth at the late season. These results are in agreement with those obtained by Makram et al., (1981) and Steve et al., (2003).

Number of nodes per plant was insignificantly affected by the application time of nitrogen with mepiquate chloride, in both seasons (Table 3). On the other hand, 
the mean length of internodes was significantly increased in case of untreated plants by mepiquate chloride. These results proved that the increase in main stem length of the control plants was due to the increase in internode length rather than the increase in number of nodes per plant.

Table 3. Effect of application time treatments of mepiquat chloride and nitrogen fertilization on cotton plant height at harvest, number of nodes per plant, length of internode and number of fruiting branches/plant in 2003 and 2004 seasons.

\begin{tabular}{|c|c|c|c|c|c|c|c|c|}
\hline Characters & \multicolumn{2}{|c|}{$\begin{array}{l}\text { Plant height at } \\
\text { harvest }(\mathrm{cm})\end{array}$} & \multicolumn{2}{|c|}{$\begin{array}{c}\text { No. of nodes/ } \\
\text { Plant }\end{array}$} & \multicolumn{2}{|c|}{$\begin{array}{l}\text { Internode } \\
\text { length }(\mathrm{cm})\end{array}$} & \multicolumn{2}{|c|}{$\begin{array}{c}\text { No. of fruiting } \\
\text { branches/ } \\
\text { plant }\end{array}$} \\
\hline Treatments & 2003 & 2004 & 2003 & 2004 & 2003 & 2004 & 2003 & 2004 \\
\hline$(1 / 2+1 / 2 N)+(1 / 2+1 / 2 M C)$ & 119.3 & 110.2 & 21.81 & 18.85 & 5.47 & 5.85 & 14.18 & 10.99 \\
\hline$(1 / 2+1 / 2 N)+(1 / 2+1 / 4+1 / 4 M C)$ & 117.7 & 85.1 & 21.20 & 18.00 & 5.55 & 4.73 & 14.03 & 10.06 \\
\hline$(1 / 2+1 / 2 N)+(1 / 4+1 / 2+1 / 4 M C)$ & 117.7 & 97.8 & 21.75 & 18.81 & 5.41 & 5.20 & 14.11 & 10.71 \\
\hline$(1 / 3+1 / 3+1 / 3 N)+(1 / 2+1 / 2 M C)$ & 121.0 & 104.9 & 21.63 & 18.89 & 5.59 & 5.55 & 13.96 & 10.78 \\
\hline$(1 / 3+1 / 3+1 / 3 N)+(1 / 2+1 / 4+1 / 4 M C)$ & 117.8 & 82.6 & 21.41 & 18.30 & 5.50 & 4.51 & 14.00 & 10.40 \\
\hline$(1 / 3+1 / 3+1 / 3 N)+(1 / 4+1 / 2+1 / 4 M C)$ & 117.3 & 86.6 & 21.70 & 18.46 & 5.41 & 4.69 & 14.26 & 10.18 \\
\hline Control $(1 / 2+1 / 2 N)+(0.0 \mathrm{MC})$ & 130.3 & 140.3 & 21.56 & 19.80 & 6.04 & 7.09 & 13.35 & 10.43 \\
\hline L.S.D at $5 \%$ & 3.12 & 9.48 & N.S & N.S & 0.20 & 0.62 & 0.44 & N.S \\
\hline
\end{tabular}

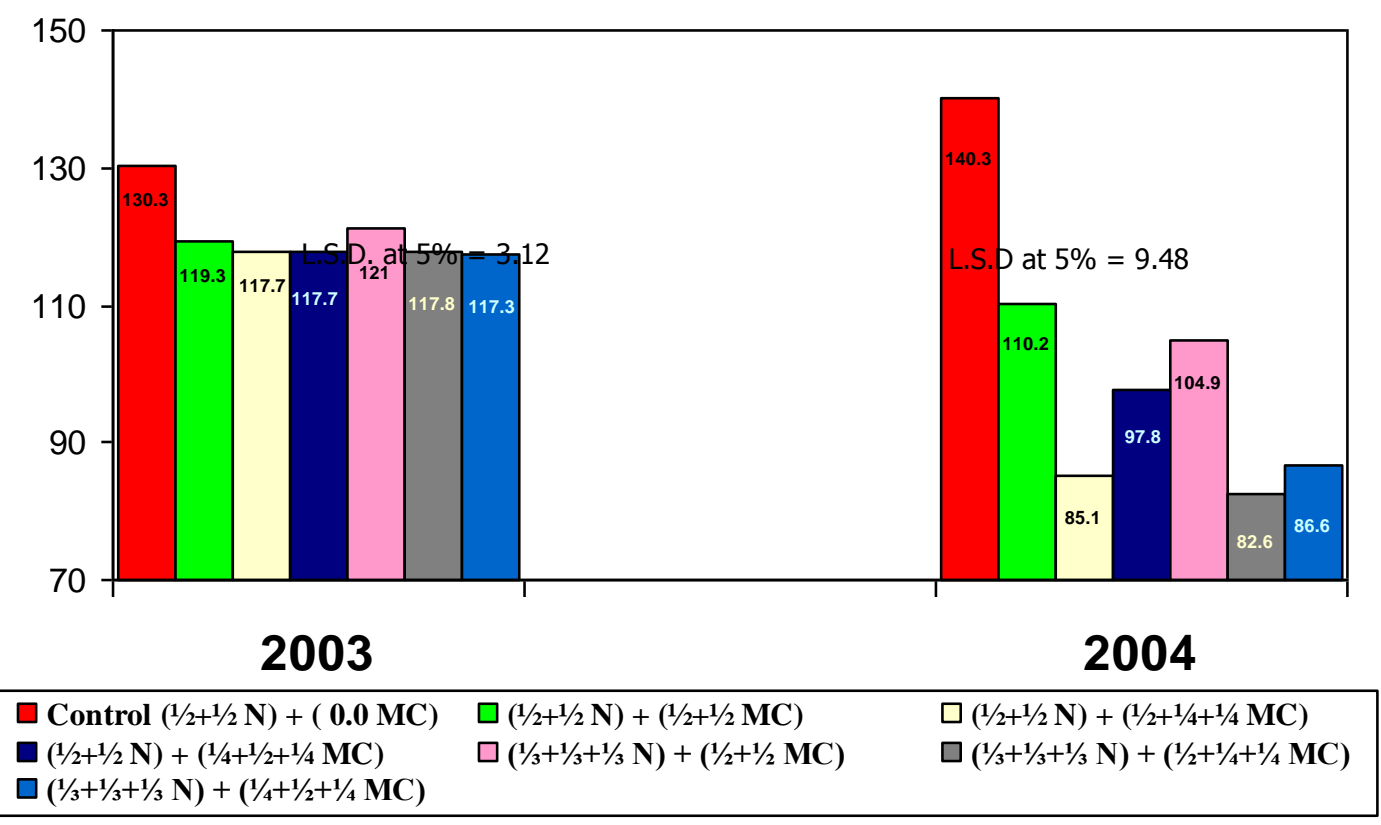

Figure 1. Effect of application time treatments of mepiquate chloride and nitrogen fertilization on cotton plant height at harvest $(\mathrm{cm})$ in 2003 and 2004 seasons. 
Generally, there was a tendency of decreasing internode length in favour of splitting the mepiquate chloride to two doses. These results might be an indication that splitting mepiquate chloride to three doses is better in controlling the vegetative growth than two doses. Similar results were obtained by Makram et al., (1981).

Regarding number of fruiting branches per plant, it was insignificantly affected by nitrogen and mepiquate chloride application time, in 2004 season, while in 2003, the effect was significant. However, in both seasons, the differences between means were slight. This could be due to the slight effect on number of nodes per plant by previous treatments. Similar results were obtained by Abdel-Al (1998).

\section{2- Effect on specific leaf weight, specific leaf area and fresh/dry weight ratio}

Table (4) and Fig. (2) clear that in both seasons, specific leaf weight (SLW) was increased significantly in favour of cotton plants treated by mepiquate chloride as compared to the control check, where nitrogen fertilization in three equal doses $(1 / 3+1 / 3+1 / 3)$ plus mepiquate chloride in three doses $(1 / 4+1 / 2+1 / 4)$ gave the highest values of specific leaf weight, in both seasons. This character expressed the higher rate of photosynthetic activity for mepiquate chloride treated plants (Moursi, 1977). On the other hand, the specific leaf area (SLA) was increased in favour of the control treatments, where this character measured the leaf density or thickness (Hunt, 1982).

Table 4. Effect of application time treatments of mepiquate chloride and nitrogen fertilization on cotton specific leaf weight, specific leaf area and fresh/dry weight ratio in 2003 and 2004 seasons.

\begin{tabular}{|c|c|c|c|c|c|c|}
\hline \multirow{2}{*}{$\begin{array}{l}\text { Characters } \\
\text { Treatments }\end{array}$} & \multicolumn{2}{|c|}{$\begin{array}{l}\text { Specific leaf weight } \\
\left(\mathrm{mg} / \mathrm{cm}^{2}\right)\end{array}$} & \multicolumn{2}{|c|}{$\begin{array}{c}\text { Specific leaf area } \\
\left(\mathrm{cm}^{2} / \mathrm{mg}\right)\end{array}$} & \multicolumn{2}{|c|}{$\begin{array}{c}\text { Fresh/Dry weight ratio } \\
\text { (gm) }\end{array}$} \\
\hline & 2003 & 2004 & 2003 & 2004 & 2003 & 2004 \\
\hline$(1 / 2+1 / 2 N)+(1 / 2+1 / 2 M C)$ & 0.69 & 0.67 & 1.46 & 1.49 & 2.96 & 2.25 \\
\hline$(1 / 2+1 / 2 N)+(1 / 2+1 / 4+1 / 4 M C)$ & 0.67 & 0.66 & 1.50 & 1.54 & 2.78 & 2.11 \\
\hline$(1 / 2+1 / 2 N)+(1 / 4+1 / 2+1 / 4 M C)$ & 0.68 & 0.69 & 1.47 & 1.47 & 2.74 & 2.10 \\
\hline$(1 / 3+1 / 3+1 / 3 N)+(1 / 2+1 / 2 M C)$ & 0.70 & 0.72 & 1.43 & 1.40 & 2.77 & 2.02 \\
\hline$(1 / 3+1 / 3+1 / 3 N)+(1 / 2+1 / 4+1 / 4 M C)$ & 0.68 & 0.66 & 1.47 & 1.53 & 2.79 & 2.17 \\
\hline$(1 / 3+1 / 3+1 / 3 N)+(1 / 4+1 / 2+1 / 4 M C)$ & 0.74 & 0.73 & 1.35 & 1.38 & 3.02 & 2.08 \\
\hline Control $(1 / 2+1 / 2 N)+(0.0 M C)$ & 0.60 & 0.57 & 1.67 & 1.79 & 3.16 & 2.41 \\
\hline L.S.D at $5 \%$ & 0.05 & 0.07 & 0.10 & 0.17 & N.S & N.S \\
\hline
\end{tabular}

Previous results might be due to the effect of mepiquate chloride which terminated plant growth and increased leaf photosynthetic activity, that resulted in much formation of leaf assimilates necessary for increasing the fruiting capacity. Similar results were obtained by Munier et al., (1995).

With respect to fresh/dry weight ratio, it was insignificantly affected by different treatments used, in both seasons (Table 4). But, there was a tendency of increasing 
this ratio in case of the control plants. This increase might be an indicator that the untreated plants by mepiquate chloride tended to have more succulent leaves as a result of the increase of vegetative growth (Hunt, 1982) as compared to the treated plants by mepiquate chloride.

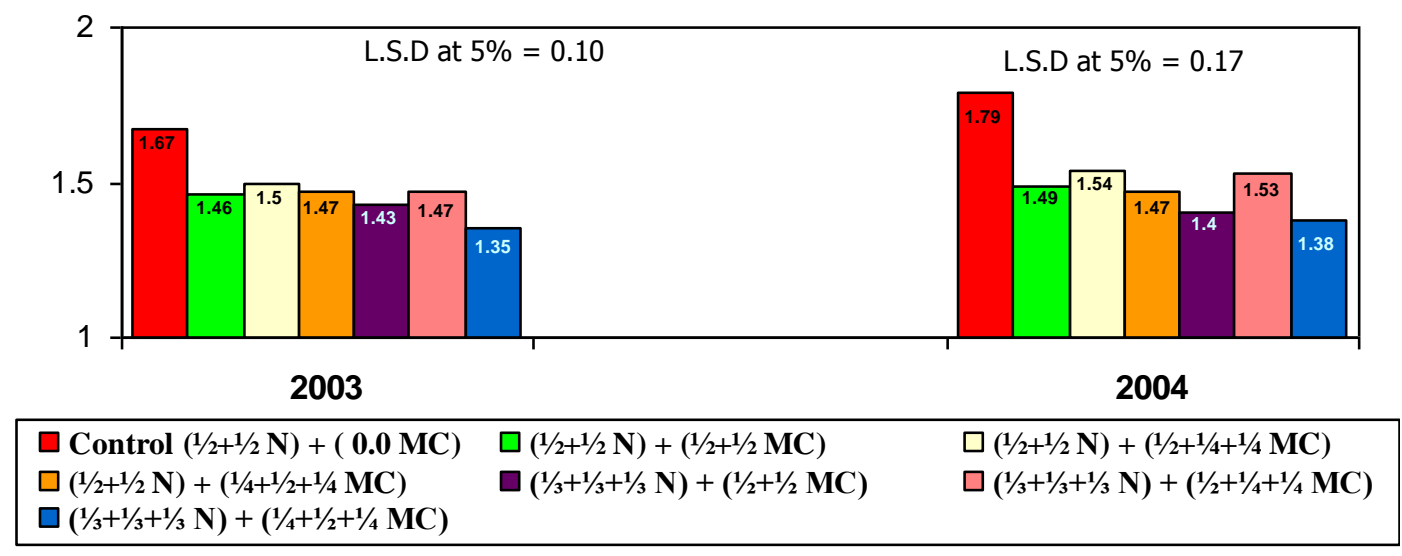

Figure 2. Effect of application time treatments of mepiquate chloride and nitrogen fertilization on cotton specific leaf area in 2003 and 2004 seasons.

Generally, previous results on plant growth revealed that mepiquate chloride decreased plant height by decreasing internode length without affecting number of nodes per plant and number of sympodia per plant. At the mean time, mepiquate chloride increased photosynthetic activity of the leaves and decreased leaf thickness as compared to the control. Also, mepiquate chloride depresses the succulent phenomenon resulted from increasing plant growth. Similar results were obtained by Ibrahim and Moftah (1997).

\section{B- Effect of application time treatments of mepiquate chloride and nitrogen fertilization on yield and yield components}

\section{1- Effect on number of open bolls, boll weight and seed cotton yield per plant}

Results present in Table (5) and illustrated in Fig. (3) indicate that number of open bolls per plant was significantly increased, in both seasons, in favour of cotton plants treated by mepiquate chloride. 
Table 5. Effect of application time treatments of mepiquate chloride and nitrogen fertilization on number of open bolls, boll weight and seed cotton yield per plant in 2003 and 2004 seasons.

\begin{tabular}{|l|c|c|c|c|c|c|}
\hline & \multicolumn{2}{|c|}{$\begin{array}{r}\text { No. of open } \\
\text { bolls/plant }\end{array}$} & \multicolumn{2}{c|}{ Boll weight $(g)$} & \multicolumn{2}{c|}{$\begin{array}{c}\text { Seed cotton } \\
\text { yield/plant }(g)\end{array}$} \\
\hline Treatments & 2003 & 2004 & 2003 & 2004 & 2003 & 2004 \\
\hline$(1 / 2+1 / 2 N)+(1 / 2+1 / 2 M C)$ & 11.5 & 10.9 & 2.37 & 2.74 & 27.26 & 29.87 \\
\hline$(1 / 2+1 / 2 N)+(1 / 2+1 / 4+1 / 4 M C)$ & 12.1 & 11.4 & 2.27 & 2.67 & 27.47 & 30.44 \\
\hline$(1 / 2+1 / 2 N)+(1 / 4+1 / 2+1 / 4 M C)$ & 11.8 & 10.9 & 2.42 & 2.74 & 28.56 & 29.87 \\
\hline$(1 / 3+1 / 3+1 / 3 N)+(1 / 2+1 / 2 M C)$ & 11.2 & 12.2 & 2.36 & 2.53 & 26.43 & 30.87 \\
\hline$(1 / 3+1 / 3+1 / 3 N)+(1 / 2+1 / 4+1 / 4 M C)$ & 12.5 & 11.7 & 2.37 & 2.56 & 29.63 & 29.95 \\
\hline$(1 / 3+1 / 3+1 / 3 N)+(1 / 4+1 / 2+1 / 4 M C)$ & 12.8 & 10.8 & 2.32 & 2.71 & 29.70 & 29.27 \\
\hline Control $(1 / 2+1 / 2 N)+(0.0$ MC) & 10.2 & 10.1 & 2.49 & 2.71 & 25.40 & 27.37 \\
\hline L.S.D at $5 \%$ & 1.85 & 1.12 & $N . S$ & $N . S$ & 2.84 & N.S \\
\hline
\end{tabular}

The maximum value of open bolls/plant was obtained when nitrogen fertilization was applied in three separate doses $(1 / 3+1 / 3+1 / 3)$ plus mepiquate chloride in three doses $(1 / 4+1 / 2+1 / 4))$ in 2003 season, while in 2004 season it was obtained from the treatment $(1 / 3+1 / 3+1 / 3 N)+(1 / 2+1 / 2 M C)$. On the other hand, boll weight was insignificantly affected by different mepiquate chloride and nitrogen treatments. Seed cotton yield per plant was significantly affected in 2003 season only in favour of cotton plants treated by mepiquate chloride. In the second season, the same trend was obtained without significant differences between means.

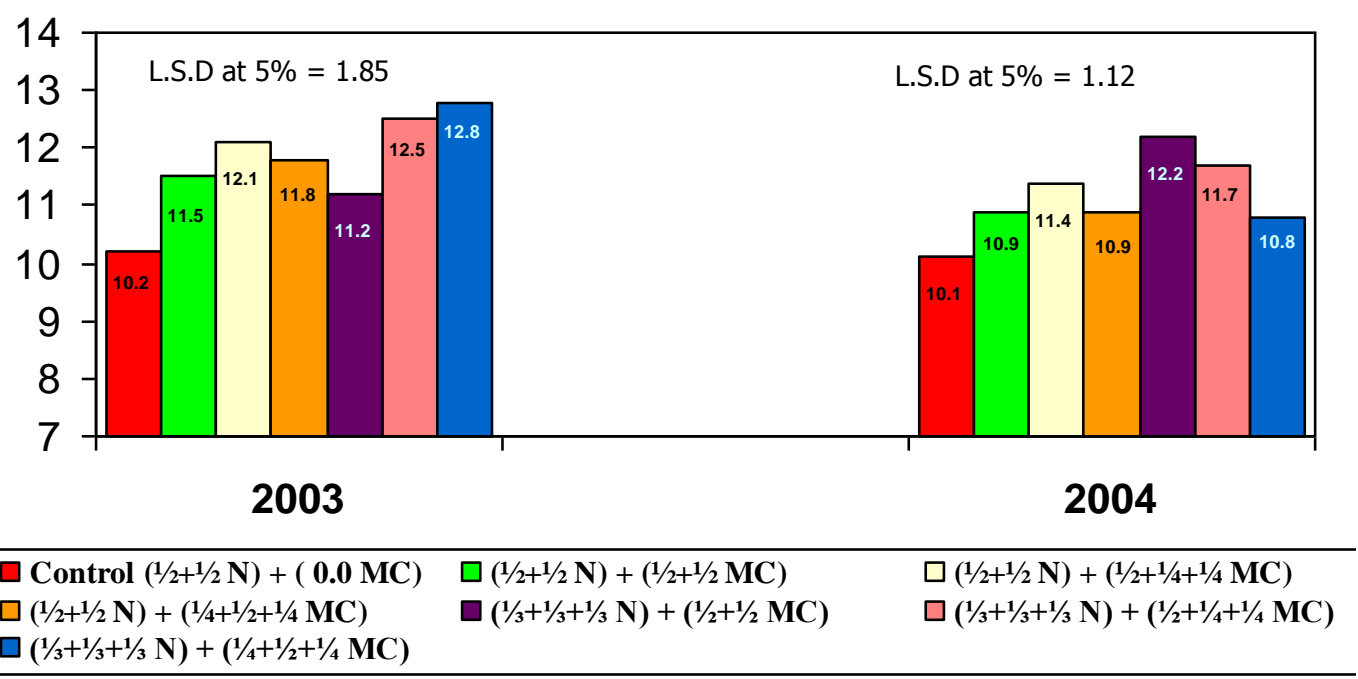

Figure 3. Effect of application time treatments of mepiquat chloride and nitrogen fertilization on number of opened bolls/plant in 2003 and 2004 seasons. 
However, the increase in number of open bolls per plant for treated cotton plants by mepiquate chloride might be due to the effect of mepiquate chloride in terminating plant growth. At the mean time, it increased the photosynthetic activity which resulted in producing more assimilates used for producing more boll setting per plant. Therefore, seed cotton yield per plant followed the same trend of open bolls even with unaffected boll weight. Similar results were obtained by Kassem \& Namich (2003).

\section{2- Effect on number of plants at harvest, seed cotton yield per feddan, lint percentage and seed index}

Table (6) reveal that the number of plants at harvest was insignificantly affected by different treatments under study. This means that this factor had no effect on the yield per feddan rather than the previous treatments. Similar results were obtained by Makram et al (1981).

Table 6. Effect of application time treatments of mepiquate chloride and nitrogen fertilization on number of plants at harvest, seed cotton yield per feddan, lint percentage and seed index in 2003 and 2004 seasons.

\begin{tabular}{|c|c|c|c|c|c|c|c|c|}
\hline \multirow{2}{*}{$\begin{array}{l}\text { Characters } \\
\text { Treatments }\end{array}$} & \multicolumn{2}{|c|}{$\begin{array}{c}\text { No. of plants at } \\
\text { harvest } \\
\text { (1000plant/fed.) }\end{array}$} & \multicolumn{2}{|c|}{$\begin{array}{l}\text { Seed cotton yield } \\
\text { (ken./fed.) }\end{array}$} & \multicolumn{2}{|c|}{$\begin{array}{l}\text { Lint percentage } \\
\text { (\%) }\end{array}$} & \multicolumn{2}{|c|}{$\begin{array}{l}\text { Seed index } \\
\text { (g) }\end{array}$} \\
\hline & 2003 & 2004 & 2003 & 2004 & 2003 & 2004 & 2003 & 2004 \\
\hline$(1 / 2+1 / 2 N)+(1 / 2+1 / 2 M C)$ & 56.59 & 60.96 & 9.38 & 9.02 & 39.3 & 39.1 & 10.33 & 10.89 \\
\hline$(1 / 2+1 / 2 N)+(1 / 2+1 / 4+1 / 4 M C)$ & 56.12 & 61.18 & 9.35 & 8.89 & 39.2 & 38.3 & 10.25 & 11.27 \\
\hline$(1 / 2+1 / 2 N)+(1 / 4+1 / 2+1 / 4 M C)$ & 56.34 & 61.41 & 9.58 & 9.01 & 39.1 & 38.4 & 10.29 & 10.99 \\
\hline$(1 / 3+1 / 3+1 / 3 N)+(1 / 2+1 / 2 M C)$ & 55.25 & 60.92 & 9.14 & 8.99 & 39.3 & 39.1 & 10.23 & 10.89 \\
\hline$(1 / 3+1 / 3+1 / 3 N)+(1 / 2+1 / 4+1 / 4 M C)$ & 55.35 & 59.71 & 9.18 & 8.66 & 39.2 & 38.0 & 10.59 & 11.19 \\
\hline$(1 / 3+1 / 3+1 / 3 N)+(1 / 4+1 / 2+1 / 4 M C)$ & 55.35 & 61.55 & 9.45 & 9.43 & 38.9 & 38.4 & 10.17 & 11.04 \\
\hline Control $(1 / 2+1 / 2 N)+(0.0 \mathrm{MC})$ & 55.86 & 57.65 & 8.58 & 7.89 & 38.9 & 38.6 & 10.12 & 10.41 \\
\hline L.S.D at $5 \%$ & N.S & N.S & 0.48 & 0.78 & N.S & N.S & N.S & 0.42 \\
\hline
\end{tabular}

Table (6) and Fig. (4) show also that the yield of seed cotton per feddan was increased significantly in case of treated cotton plants by mepiquate chloride, where the maximum value was obtained when nitrogen fertilization $(\mathrm{N})$ was applied in two separate doses $(1 / 2+1 / 2)$ plus mepiquate chloride (MC) in three doses $(1 / 4+1 / 2+1 / 4)$ in 2003 season.

In 2004 season, the maximum value was obtained from nitrogen fertilization (N) treatment $(1 / 3+1 / 3+1 / 3)$ plus mepiquate chloride $(M C)$ in three doses $(1 / 4+1 / 2+1 / 4)$. These results are reasonably with the results of number of open bolls per plant and yield per plant. Similar results were obtained by Makram et al., (1981), Sawan et al., (2006) and Stephens et al., (2007). 


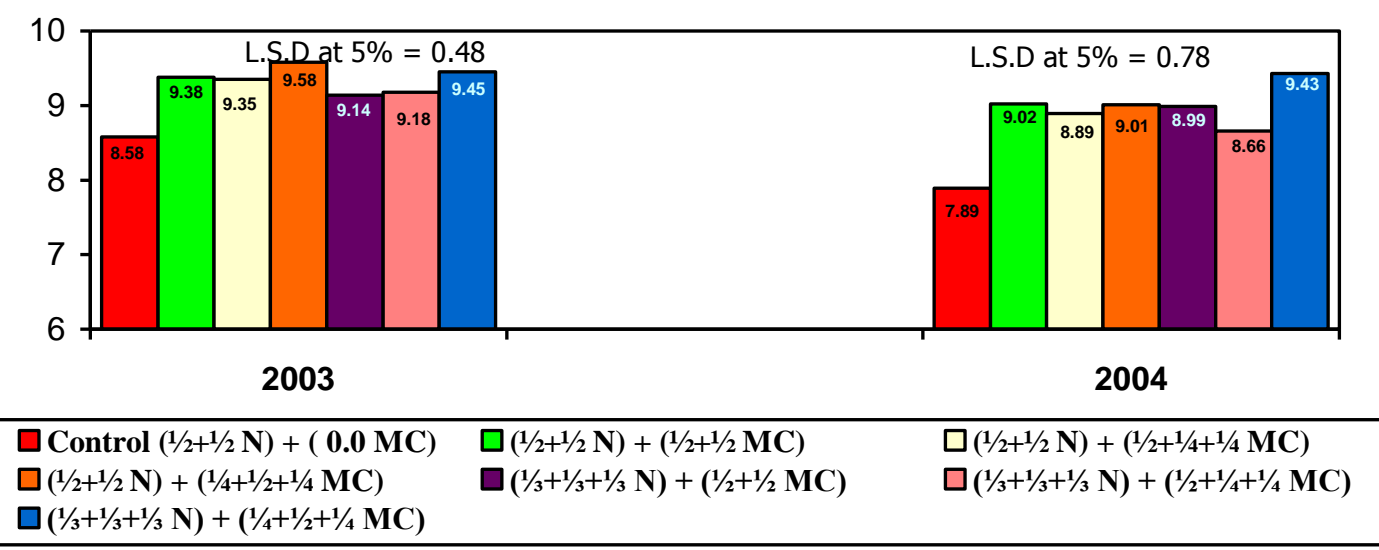

Figure 4. Effect of application time treatments of mepiquate chloride and nitrogen fertilization on seed cotton yield per feddan in 2003 and 2004 seasons.

The data present in Table (6) clear that lint percentage was insignificantly affected by mepiquate chloride treatments, in both seasons. On the other hand, seed index was significantly affected in one season out of two where the highest seed index value was obtained with the application of nitrogen fertilizer in two separate doses $(1 / 2+1 / 2)$ plus mepiquate chloride in three doses $(1 / 2+1 / 4+1 / 4)$.

However, there was a tendency of increasing both characters in favour of mepiquate chloride treatments. This could be due to more maturation of seed and lint quality. These results are in line with those obtained by Abdel-Al et al., (1986), Makram (1988).

\section{C- Effect of application time treatments of mepiquate chloride and nitrogen fertilization on earliness characters}

The data present in Table (7) and Fig. (5) clear that number of days from sowing date to first flower appearance and first boll opening was significantly increased in favour of the control treatment, in both seasons.

Table 7. Effect of application time treatments of mepiquate chloride and nitrogen fertilization on number of days to first flower and number of days to first opened boll in 2003 and 2004 seasons.

\begin{tabular}{|l|c|c|c|c|}
\hline \multirow{2}{*}{ Characters } & \multicolumn{2}{|c|}{ No. of days to first flower } & \multicolumn{2}{c|}{$\begin{array}{c}\text { No. of days to first opened } \\
\text { boll }\end{array}$} \\
\hline Treatments & 2003 & 2004 & 2003 & 2004 \\
\hline$(1 / 2+1 / 2 N)+(1 / 2+1 / 2 M C)$ & 72.6 & 73.3 & 122.2 & 126.6 \\
\hline$(1 / 2+1 / 2 N)+(1 / 2+1 / 4+1 / 4 M C)$ & 73.4 & 72.7 & 123.2 & 126.1 \\
\hline$(1 / 2+1 / 2 N)+(1 / 4+1 / 2+1 / 4 M C)$ & 69.4 & 70.8 & 120.5 & 123.6 \\
\hline$(1 / 3+1 / 3+1 / 3 N)+(1 / 2+1 / 2 M C)$ & 70.9 & 73.3 & 121.9 & 126.4 \\
\hline$(1 / 3+1 / 3+1 / 3 N)+(1 / 2+1 / 4+1 / 4 M C)$ & 70.5 & 71.7 & 122.9 & 125.7 \\
\hline$(1 / 3+1 / 3+1 / 3 N)+(1 / 4+1 / 2+1 / 4 M C)$ & 69.2 & 70.4 & 119.7 & 123.3 \\
\hline Control $(1 / 2+1 / 2 N)+(0.0 M C)$ & 76.1 & 77.9 & 126.9 & 128.9 \\
\hline L.S.D at $5 \%$ & 1.82 & 1.80 & 2.13 & 1.64 \\
\hline
\end{tabular}


The shortest periods for previous treatments were obtained from the $(1 / 3+1 / 3+1 / 3$ $N)+(1 / 4+1 / 2+1 / 4 M C)$, which seemed to terminate the vegetative growth early rather than other treatments. These results might be due to the controlling effect of the little dose of mepiquate chloride, a.i. $12.5 \mathrm{~g}$ per feddan at squaring stage which induced the better balance between vegetative growth and fruiting capacity. Therefore, the treated cotton plants were brought to early maturity in the season rather than untreated plants. Similar results were obtained by El-Shahawy \& Abd El-Malik (2000).

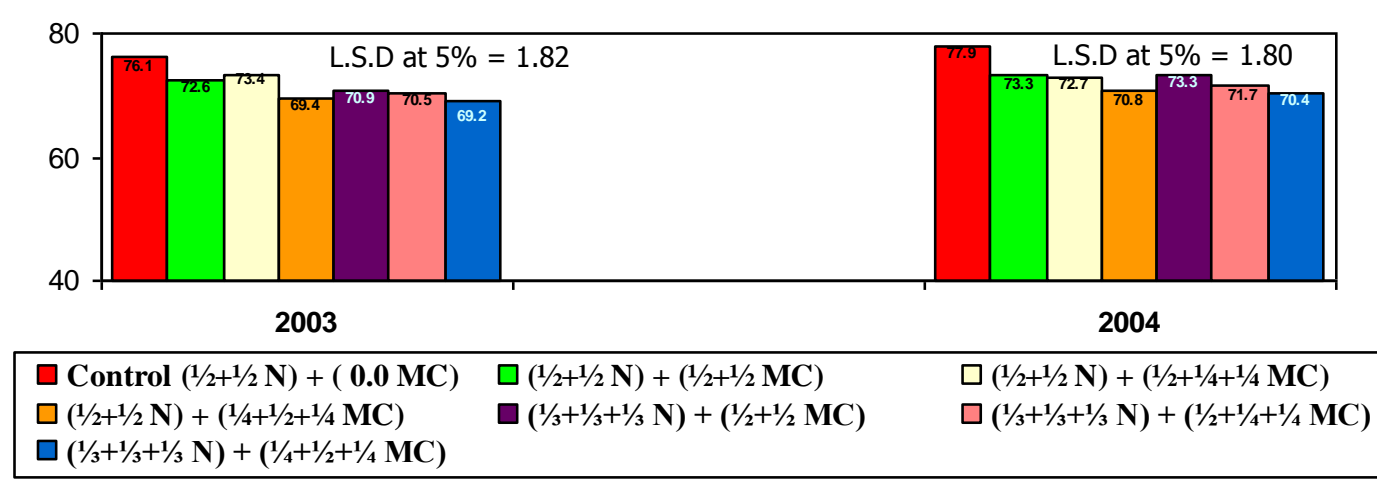

Figure 5. Effect of application time treatments of mepiquate chloride and nitrogen fertilization on number days to first flower in 2003 and 2004 seasons.

\section{D- Effect of application time treatments of mepiquate chloride and nitrogen fertilization on fiber quality}

Table (8) clear that upper half mean was significantly increased in 2004 season only. Generally, there was a tendency of increasing this character by mepiquate chloride treated plants. The most pronounced treatment was $(1 / 3+1 / 3+1 / 3 \mathrm{~N})+$ $(1 / 4+1 / 2+1 / 4 M C)$, in both seasons and $(1 / 2+1 / 2 N)+(1 / 2+1 / 4+1 / 4 M C)$, in 2004 season. These results might be an indication of that mepiquate chloride increased the fiber length. Similar results were obtained by Nawar et al., (1986).

On the other hand, uniformity index, fiber strength and fiber elongation percentage were insignificantly affected by mepiquate chloride, in both seasons. Similar results were obtained by Frank et al., (2005). 
Table 8. Effect of application time treatments of mepiquate chloride and nitrogen fertilization on upper half mean length, uniformity index, fiber strength and fiber elongation in 2003 and 2004 seasons.

\begin{tabular}{|c|c|c|c|c|c|c|c|c|}
\hline \multirow{3}{*}{$\begin{array}{l}\text { Characters } \\
\text { Treatments }\end{array}$} & \multicolumn{4}{|c|}{ Fiber Length parameters } & \multicolumn{4}{|c|}{ Fiber bundle tensile properties } \\
\hline & \multicolumn{2}{|c|}{$\begin{array}{l}\text { Upper half mean } \\
(\mathrm{mm})\end{array}$} & \multicolumn{2}{|c|}{$\begin{array}{c}\text { Uniformity index } \\
\text { (U.I) (\%) }\end{array}$} & \multicolumn{2}{|c|}{$\begin{array}{c}\text { Fiber strength. } \\
(\mathrm{g} / \mathrm{tex})\end{array}$} & \multicolumn{2}{|c|}{$\begin{array}{c}\text { Fiber elongation } \\
(\%)\end{array}$} \\
\hline & 2003 & 2004 & 2003 & 2004 & 2003 & 2004 & 2003 & 200 \\
\hline$(1 / 2+1 / 2 N)+(1 / 2+1 / 2 M C)$ & 31.8 & 31.8 & 88.1 & 87.7 & 41.7 & 40.5 & 7.19 & 6.61 \\
\hline$(1 / 2+1 / 2 N)+(1 / 2+1 / 4+1 / 4 M C)$ & 31.6 & 32.5 & 87.8 & 88.0 & 41.6 & 40.4 & 7.11 & 6.68 \\
\hline$(1 / 2+1 / 2 N)+(1 / 4+1 / 2+1 / 4 M C)$ & 31.7 & 31.6 & 88.2 & 87.4 & 41.9 & 40.3 & 7.13 & 6.63 \\
\hline$(1 / 3+1 / 3+1 / 3 N)+(1 / 2+1 / 2 M C)$ & 31.7 & 31.8 & 88.2 & 88.0 & 41.5 & 40.5 & 7.09 & 6.73 \\
\hline$(1 / 3+1 / 3+1 / 3 N)+(1 / 2+1 / 4+1 / 4 M C)$ & 31.6 & 32.1 & 87.9 & 87.7 & 40.8 & 39.8 & 7.10 & 6.76 \\
\hline$(1 / 3+1 / 3+1 / 3 N)+(1 / 4+1 / 2+1 / 4$ MC) & 31.9 & 32.5 & 88.1 & 87.1 & 41.1 & 39.8 & 7.08 & 6.73 \\
\hline Control $(1 / 2+1 / 2 N)+(0.0 M C)$ & 31.5 & 31.2 & 87.9 & 87.6 & 41.7 & 39.7 & 7.06 & 6.66 \\
\hline L.S.D at $5 \%$ & N.S & 0.66 & N.S & N.S & N.S & N.S & N.S & N.S \\
\hline
\end{tabular}

Table (9) reveal that micronaire value was increased significantly in both seasons in favour of treated plants by mepiquate chloride. The highest micronaire value in 2003 season was obtained from nitrogen fertilization $(\mathrm{N})$ when applied in two separate doses $(1 / 2+1 / 2)$ plus mepiquate chloride (MC) in three doses $(1 / 4+1 / 2+1 / 4)$, while in 2004 season it was obtained from nitrogen fertilization (N) in three separate doses $(1 / 3+1 / 3+1 / 3)$ plus mepiquate chloride (MC) in three doses $(1 / 4+1 / 2+1 / 4)$. This could be due to more maturation of cotton fiber. These results are in agreement with those obtained by Nawar et al (1986) and Johnson (2005). While Steve et al (2003) reported that mepiquate chloride did not affect micronaire value.

Table 9. Effect of application time treatments of mepiquate chloride and nitrogen fertilization on reflectance, yellowness and micronaire value in 2003 and 2004 seasons.

\begin{tabular}{|c|c|c|c|c|c|c|}
\hline \multirow{3}{*}{$\begin{array}{l}\text { Characters } \\
\text { Treatments }\end{array}$} & \multicolumn{4}{|c|}{ Colour characters } & \multirow{2}{*}{\multicolumn{2}{|c|}{ Micronaire value }} \\
\hline & \multicolumn{2}{|c|}{ Reflectance (Rd \%) } & \multicolumn{2}{|c|}{ Yellowness (+b) } & & \\
\hline & 2003 & 2004 & 2003 & 2004 & 2003 & 2004 \\
\hline$(1 / 2+1 / 2 N)+(1 / 2+1 / 2 M C)$ & 65.6 & 65.8 & 12.5 & 12.5 & 5.09 & 4.83 \\
\hline$(1 / 2+1 / 2 N)+(1 / 2+1 / 4+1 / 4 M C)$ & 65.7 & 66.1 & 12.7 & 12.5 & 5.10 & 4.94 \\
\hline$(1 / 2+1 / 2 N)+(1 / 4+1 / 2+1 / 4 M C)$ & 65.7 & 66.3 & 12.8 & 12.6 & 5.11 & 4.95 \\
\hline$(1 / 3+1 / 3+1 / 3 N)+(1 / 2+1 / 2 M C)$ & 66.0 & 66.3 & 12.8 & 12.5 & 5.03 & 4.86 \\
\hline $\begin{array}{l}(1 / 3+1 / 3+1 / 3 \quad N)+(1 / 2+1 / 4+1 / 4 \\
M C)\end{array}$ & 65.7 & 66.1 & 12.6 & 12.6 & 5.10 & 4.98 \\
\hline $\begin{array}{l}(1 / 3+1 / 3+1 / 3 N)+(1 / 4+1 / 2+1 / 4 \\
M C)\end{array}$ & 65.7 & 66.4 & 12.6 & 12.6 & 5.08 & 4.99 \\
\hline $\begin{array}{l}\text { Control }(1 / 2+1 / 2 N)+(0.0 \\
M C)\end{array}$ & 65.3 & 65.7 & 12.7 & 12.4 & 4.94 & 4.64 \\
\hline L.S.D at $5 \%$ & N.S & N.S & N.S & N.S & 0.12 & 0.14 \\
\hline
\end{tabular}


With respect to colour characters reflectance and yellowness (Table 9), both were not affected by mepiquate chloride in both seasons and the differences between means were very slight. Similar results were obtained by Frank et al., (2005).

\section{CONCLUSION}

The results obtained in this study could lead us to a package of recommendations which seems to be useful for increasing the cotton yield production in quantity and quality. These recommendations could be summarized in the following points

1. Spraying mepiquate chloride on cotton plants terminates lateral plant growth, hastens the yield maturity which enables the cotton plants to escape from boll worms infections at late season.

2. The best application of mepiquate chloride is splitting the dose of $50 \mathrm{~g}$. a.i./feddan at different plant stages i.e., pinhead square, beginning of flowering and after flowering by two weeks where each stage received 12.5, 25 and 12.5 g. a.i./feddan, respectively.

3. It is profitable to split the nitrogen fertilization dose $(60 \mathrm{Kg} / \mathrm{feddan})$ to three equal doses $(20+20+20 \mathrm{Kg} \mathrm{N})$ applied before the second, third and fourth irrigations. This application maximizes the efficiency use of mepiquate chloride.

\section{REFERENCES}

1. A. S. T. M. 1986. American Society for Testing and Materials. D-4605., Vol. 07, No 1, Easton, MD, USA.

2. Abdel-Al, M. H. 1998. Response of Giza 85 cotton cultivar to the growth regulators Pix and Atonik. Egypt J. Agric. Res., 76(3): 1173-1181.

3. Abdel-Al, M. H., T. Eid Etidal, M. S. Esmail, M. H. El-Akkad and A. T. Hegab. 1986. Response of Egyptian cotton plants to mepiquat chloride with varying concentrations and time of application. Annals Agric. Sci., Ain Shams Univ., Cairo Egypt, 31(2): 1063-1076.

4. El-Shahawy, M. I. and R. R. Abd El-Malik. 2000. Response of Giza 87 cotton cultivar to mepiquat chloride (Pix) and nitrogen fertilization levels. Egypt J. Agric. Res., 78(2): 769-780.

5. Frank, G., R. Bill and L. Rock. 2005. Evaluation of mepiquat chloride treatments at cutout or the latest possible cutout date. Proc. Beltwide Cotton Conf., New Orleans LA., U.S.A., (Jan. 4-7) (2): 2161. 
6. Hunt, R. 1982. Plant Growth Curves. Thomas Litho Ltd., East Kilbride, Scotland. pp: 248.

7. Ibrahim, M. E. and A.E. Moftah. 1997. The response of cotton plants to frequent irrigation and mepiquat chloride (Pix). Monoufiya J. Agric. Res., 22(3): 723-754.

8. Johnson, J. T. 2005. Effects of mepiquat pentaborate on genotypes of varying maturity. Proc. Beltwide Cotton Conf., New Orleans LA. U.S.A., (Jan. 4-7) (1): 885.

9. Kassem, M. A. and Namich, A. Alia. 2003. Response of cotton cultivar Giza 83 to mepiquat chloride (Pix) under two levels of irrigation intervals. Egypt J. Appl. Sci., 18(5): 105-121.

10. Makram, E. A., M. A. El-Ghandour and S. A. Ali. 1981. Effect of growth retardant 1, 1-dimethyl piperidinium chloride on growth, flowering and yield of Egyptian cotton (Gossypium barbadense L.). Res. Bull., Fac. Agric., Ain Shams Univ., Cairo Egypt, 1626: 1-20.

11. Makram, E. A. 1988. Cotton response to mepiquat chloride in the republic of Burundi. Annals Agric. Sci., Fac. Agric., Ain Shams Univ., Cairo Egypt, 33(2): 931-940.

12. Moursi, M. A. 1977. Principales of Field Crop Production. Egyptian Anglo Library., $1^{\text {st }}$ Ed., Egypt. pp: 568.

13. Munier, D.J., S.D. Wright and B.L. Weir. 1995. A three year summary of applying Pix at variable rates when plant height varies in a cotton field. Proc. Beltwide Cotton Conf., San Antonio TX. U.S.A., (Jan. 4-7) (2): 1085-1086.

14. Nawar, M. T., E. A. Makram and L. A. Badr. 1986. Effect of 1, 1-dimethyl piperidinium chloride (DMPC) at different application rates and time on some properties of cotton lint and yarn strength. J. Agric. Sci., Mansoura Univ., 11(1): 97-106.

15. Sawan, Z. M., S. A. Hafez, A.E. Basyony and A. R. Alkassas. 2006. Cottonseed, protein, oil yields and oil properties as affected by nitrogen fertilization and foliar application of potassium and a plant growth retardant. World J. Agric. Sci., 2(1): 56-65.

16. Snedecor, G. W. and W. G. Cochran 1980. Statistical Methods. $6^{\text {th }}$ Ed. Iowa State Univ., U.S.A. pp: 225-269.

17. Stephen, P. k. and E. K. Hensley. 2007. A reliable fruit set enhancer for cotton. Proc. Beltwide Cotton Conf., New Orleans, LA. U.S.A., (Jan. 9-12).

18. Steve, P. N., E. S. Charles and A. J. Mike. 2003. Evaluation of row spacing and mepiquat chloride in cotton. J. Cotton Sci., 7: 148-155. 
تأثير مواعيد إضافة المبيكوات كلوريد و التسميد النتروجينى علي صنف القطن

\section{1. 1 المصري جيزة}

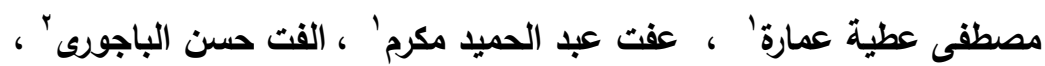

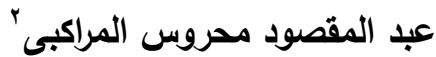

$$
\text { r. . قسم الدحاصبل - معوث القطن - مركز البحوث الزراعبة - الجيزة الزراعة - جامعة عبن شعس }
$$

أجريت تجربتان حقليتان بمحطة البحوث الزراعية بسدس بمحافظة بنى سويف فى موسمى

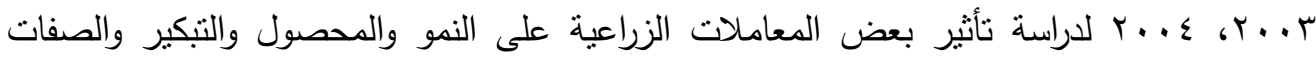
التكنولوجية للتيلة، باستخدام صنف القطن المصري جيزة .1.. وكانت المعاملات المستخدمة هي

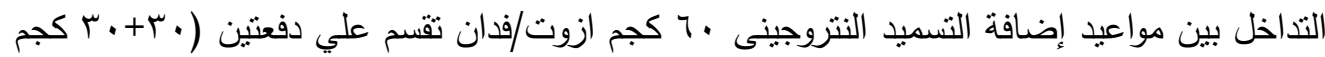

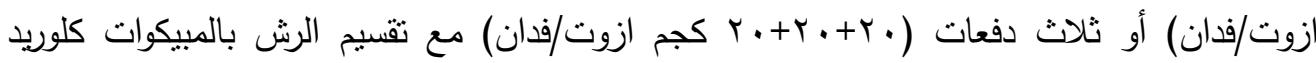
(Pix)

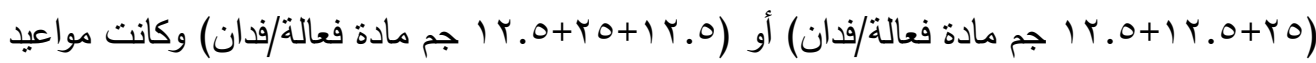
الرش هي عند مرحلة ظهور الواسوس وعند بداية التزهير وبعده بأسبوعين، وكان التصميم التجريبى المستخدم هو القطاعات الكاملة العشوائية فى أربعة مكرارت. وتتلخص أهم النتائج المتحصل عليها فيما يلى:

$$
\text { 1 - | - صفات النمو الخضري: }
$$

نقص طول النبات عند الجني وبشكل معنوي في معاملات الميبكوات كلوريد بالمقارنة بمعاملة

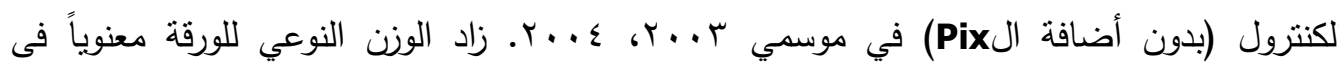
النباتات المعاملة بالمبيكوات كلوريد مقارنة بالنباتات غير المعاملة في كلا الموسمين حيث أعطت

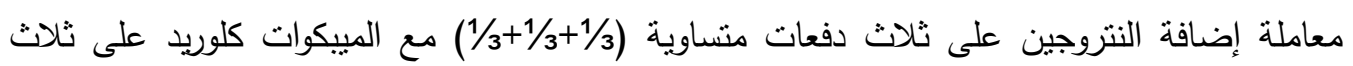
دفعات (1/1/1/2+1/4) أعلى قيم للوزن النوعي للورقة في كلا الموسمين. بالنسبة للمساحة النوعية للورقة

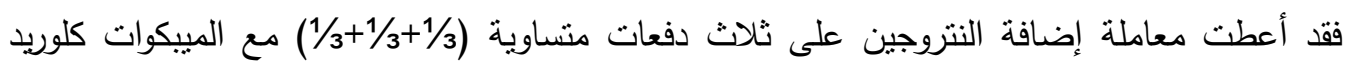

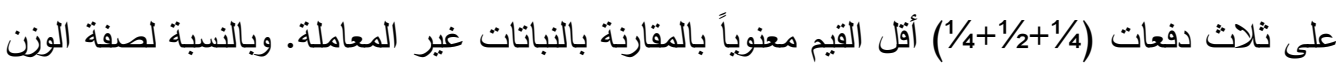

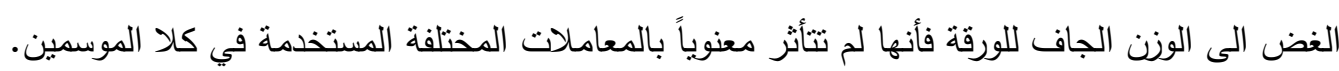

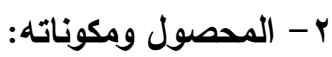

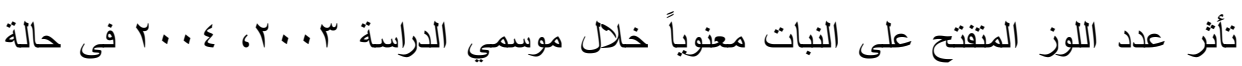

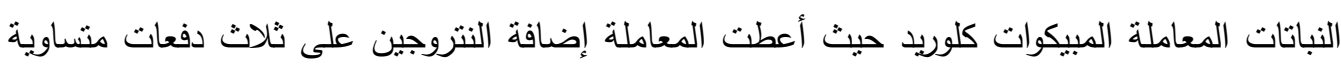

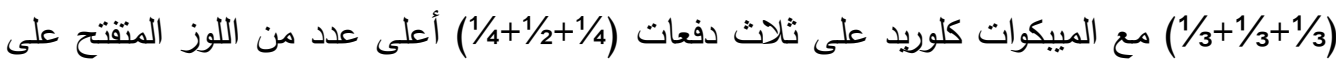

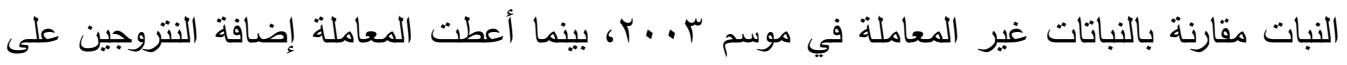

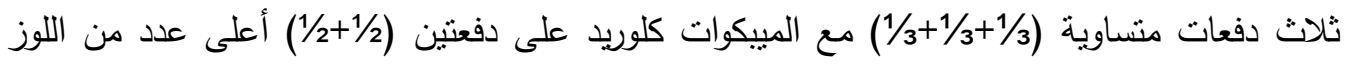

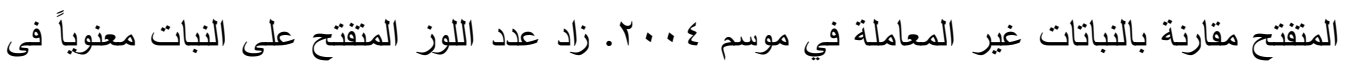


حالة النباتات غير المعاملة بالمبيكوات كلوريد في كلا الموسمين. لم يتأثز محصول النبات الفردي

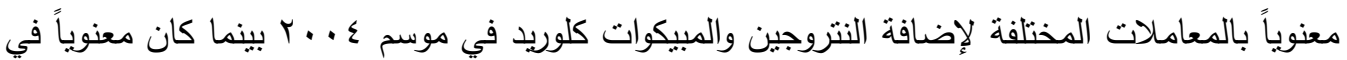

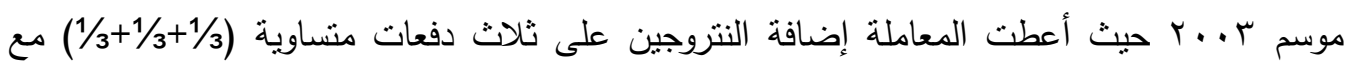

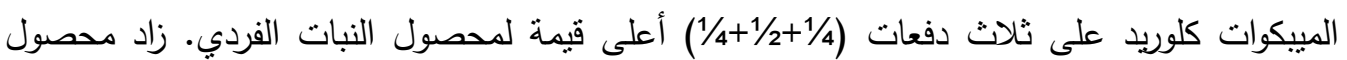

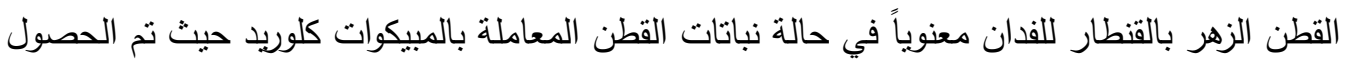

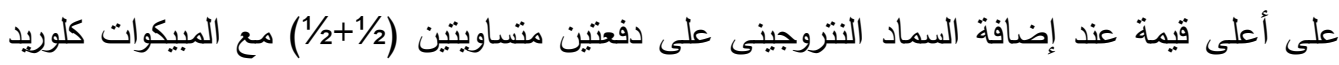

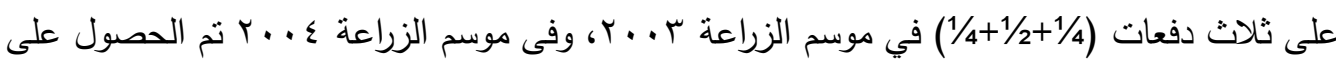

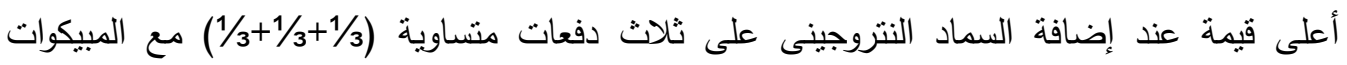

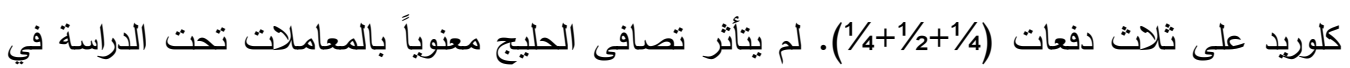
كلا الموسمين.

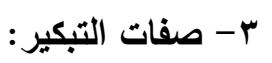
أدت جميع معاملات الرش بالمبيكوات كلوريد الي نقص معنوي في عدد الأيام من الزراعة وحتى

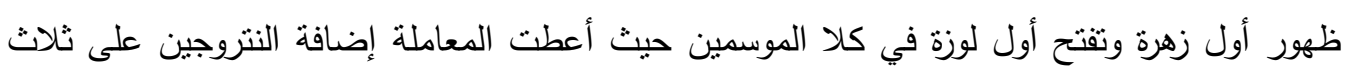

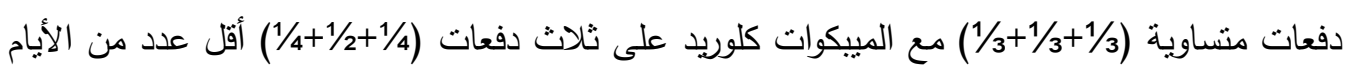

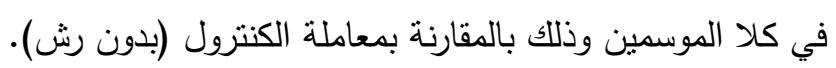

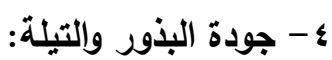

بالنسبة لصفة متوسط طول التيلة تأثرت معنوياً بالمعاملات المستخدمة في موسم واحد فقط من

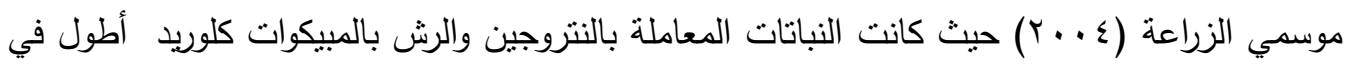

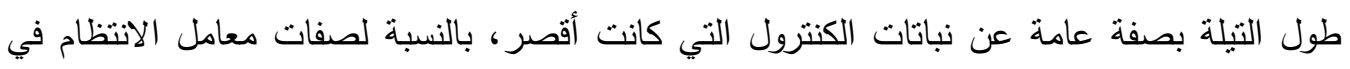
الطول والمتانة والاستطالة ونسبة الانعكاس ودرجة الاصفرار في اللون لم يتأثروا معنوياً بواسطة

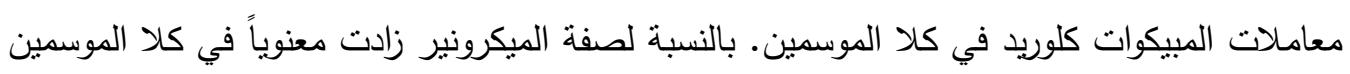
فى النباتات المعاملة بالمييكوات كلوريد حيث كانت أكثر نضجاً عن النباتات غير المعاملة خلاد موسمي الدراسة.

ومن النتائج المتحصل عليها والموضحة في هذه الدراسة فأنه يمكنتا استخلاص مجموعة من التوصيات التي قد تكون مفيدة في زيادة أنتاج محصول القطن كماً وجودةًً:

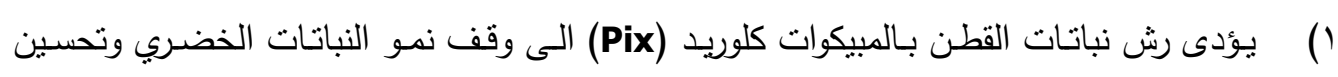
نضج المحصول والذي يُمكن نباتات القطن من الهروب من الإصابة بالآفات.

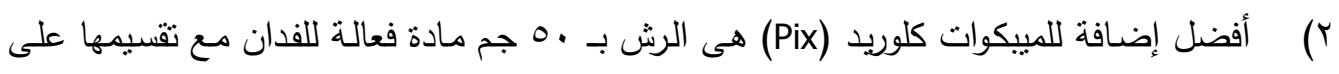

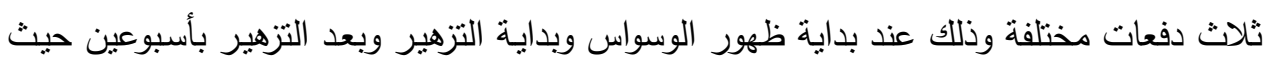

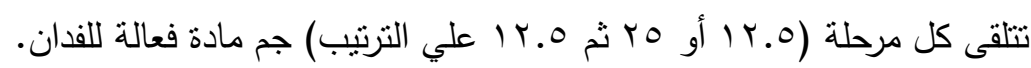

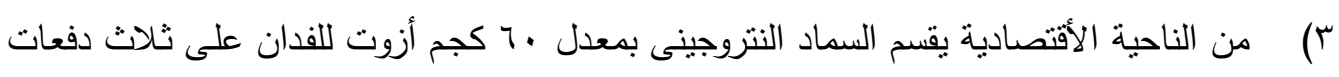

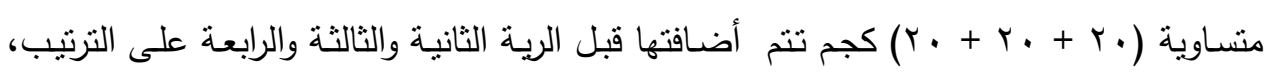
وتقسيم الإضافة هذا يعظم من كفاءة استخدام والاستفادة من الميبكوات كلوريد. 